\title{
THE MONTREAL CLASSIFICATION FOR CROHN'S DISEASE: clinical application to a Brazilian single-center cohort of 90 consecutive patients
}

\author{
Ulysses dos Santos TORRES ${ }^{1}$, Juliana OIsen RODRIGUES ${ }^{1}$, Melissa Silva Garcia JUNQUEIRA ${ }^{1}$, \\ Simone UEZATO ${ }^{1}$ and João Gomes NETINHO²
}

\begin{abstract}
Context - Crohn's disease presents very heterogeneous features from a clinical point of view, and classifying Crohn's disease patients in homogeneous subgroups in the light of genetic, molecular and clinical aspects is challenging. The Montreal Classification for Crohn's disease was proposed in 2005 as an effort to characterize Crohn's disease patients according to recent clinical and research advances in the field of inflammatory bowel disease. Since its proposition, the Montreal Classification needs an ample validation and application among different populations around the world. To date, there are no known studies applying the Montreal Classification to a Brazilian cohort of Crohn's disease patients. Objectives - To apply the Montreal Classification to a Brazilian cohort of Crohn's disease patients at a referral center for inflammatory bowel disease in Northwestern São Paulo State, Brazil. Methods - We selected 90 consecutive well-characterized Crohn's disease patients assisted at Inflammatory Bowel Disease Outpatient Clinic between January 1992 and January 2007, with a minimum follow-up of 2 years; data concerning demographic characteristics, clinical onset of disease, age at diagnosis, time of disease, location and behavior of disease, presence of extraintestinal manifestations, familial occurrence, perianal involvement, treatment with biological drugs, and history of surgical treatment were evaluated. Results - Male patients were predominant (54\%), with a mean age at diagnosis of $33 \pm 14$ years old, and a median followup of 5.5 years. Most of the patients were diagnosed between 17 and 40 years old (59\%), and had disease located in terminal ileum $(46 \%)$, with a nonstricturing, nonpenetrating behavior (71\%). Time of disease was correlated with necessity of biological treatment, disease behavior, and surgical treatment $(P<0.05)$. Conclusions - These study findings are consistent with results from other studies conducted among different populations, although a further multicentric study with a larger number of patients would be necessary to validate the Montreal Classification among Brazilian population.
\end{abstract}

HEADINGS - Crohn disease, classification.

\section{INTRODUCTION}

Crohn's disease $(\mathrm{CD})$ is a chronic inflammatory disease that can affect any part of the gastrointestinal tract; the inflammatory process is typically discontinuous, recurrent and transmural. The etiology remains unclear, although it has been suggested the involvement of genetic factors, alterations of intestinal epithelial barrier, and an abnormal mucosal immune response to normal gut microbiota ${ }^{(20)}$.

Because CD clinically exhibits very heterogeneous features, similarly to its possible multiple causal factors $^{(20)}$, a major challenge in the field of clinical investigation is to determine homogeneous subsets of patients with distinctive genetic, molecular, laboratory or clinical characteristics, which could help to recognize subphenotypes and to optimize genetic studies, as well as the search for new therapies ${ }^{(8)}$.

In 1975, as an initial effort to classify patients with CD, a classification based on anatomic location of disease was proposed; it was found that patients with ileocolonic disease had undergone surgery more frequently and had worse prognosis, in comparison to those with small bowel disease only, or colonic or perianal disease only ${ }^{(5)}$. In 1988, a new distinction was made, grouping patients in two clinical patterns, according to perforating and nonperforating manifestations of disease requiring the first surgery ${ }^{(9)}$. In 1992, the Rome Classification established additional variables, considering disease

Medical School of São José do Rio Preto (FAMERP); ${ }^{2}$ Department of Surgery, Division of Coloproctology, FAMERP, São José do Rio Preto, SP, Brazil. Correspondence: Dr. João Gomes Netinho - Rua San Francisco, 481 - Condomínio Débora Cristina - 15090-030 - São José do Rio Preto, SP, Brasil. E-mail: jgnetinho@riopreto.com.br 
Torres US, Rodrigues JO, Junqueira MSG, Uezato S, Netinho JG. The Montreal Classification for Crohn's disease: clinical application to a Brazilian single-center cohort of 90 consecutive patients

location, behavior and surgical history; 756 subgroups were created, hampering an ample clinical application ${ }^{(22)}$.

Based on disease behavior, another classification resulted from an international Working Party formed in 1996; during the World Gastroenterology Congress in Vienna, in 1998, the so-called Vienna Classification (VC) was finally presented and validated ${ }^{(8)}$. Three variables were chosen: age at diagnosis (A1, below 40 years; A2, equal to or above 40 years), disease location ( $\mathrm{L} 1$, terminal ileum, with or without cecum involvement; L2, colon; L3, ileocolon; L4, upper gastrointestinal tract), and disease behavior (B1, nonstricturing nonpenetrating; B2, stricturing; B3, penetrating). This new scheme allocated patients into 24 potential subsets. Regardless of not being largely employed in clinical practice, $\mathrm{VC}$ has been used increasingly in research studies, and its reproducibility has demonstrated to be satisfactory ${ }^{(1)}$.

In 2005, at World Congress of Gastroenterology in Montreal, a new classification was proposed by a Working Party to refine the previous $\mathrm{VC}^{(26)}$; more categories were included, allowing a more accurate disease characterization. Alterations were made in all the three variables. Into the variable age at diagnosis a new category was established, with subdivision of the group below 40 years into two new groups (A1, below or equal to 16 years; A2, 17 to 40 years); the group above 40 years was maintained, becoming A3. With relation to disease location, in the presence of upper gastrointestinal involvement, the Vienna scheme used to consider uncommon concomitant distal involvement, so that L1/L2/L3 and L4 were mutually exclusive; therefore, patients with concomitant upper and distal manifestations of disease were not properly classified. According to the new Montreal scheme, if proximal (L4) and distal (L1 to L3) manifestations are found concomitantly, L4 category must be added as a modifier, and not to be considered exclusively; if distal disease is not found, L4 remains considered exclusively. This creates seven possibilities of location: L1, L2, L3, L4, L1+L4, L2+L4, and L3+L4.

At last, considering disease behavior, perianal fistulizing disease (fistulas and/or abscesses) has been revealed different patterns from intestinal penetrating disease in respect of progression, outcome, serological markers and genotype influence ${ }^{(15,27)}$. The Montreal Classification (MC) excluded perianal fistulizing disease from B3 category (penetrating disease) and introduced a perianal disease modifier (P) that must be added to $\mathrm{B} 1, \mathrm{~B} 2$ or $\mathrm{B} 3$ categories, if perianal disease is present. There are, thus, six possibilities: B1, B2, B3, B1p, B2p, and B3p.

Although some studies around the world have been conducted to characterize CD in homogeneous subsets of patients based on $\mathrm{MC}^{(23)}$, this classification has not been yet validated or applied largely among different populations. To date, there are no known studies applying MC for CD in Brazil. The aims of this study, therefore, were to characterize a cohort of CD patients consecutively admitted and followed in a single tertiary referral center in São Paulo State, Brazil according to the $\mathrm{MC}$.

\section{METHODS}

\section{Patients and data}

We analyzed retrospectively a database compound by records of 90 consecutive $C D$ patients admitted and prospectively followed at the Inflammatory Bowel Disease (IBD) Outpatient Clinic of the Coloproctology Service from the Hospital de Base of São José do Rio Preto Medical School, a referral tertiary center for IBD in Northwestern of São Paulo State, Brazil.

The selected patients were assisted in such service from January 1992 to January 2007. To all patients the diagnosis of CD had to be of at least 2 years, with regular follow-up; thus, the MC was applied to those patients who, at the moment of this study, were under regular treatment for more than 2 years. Diagnosis of CD, as well as definition of location and behavior of the disease were based on endoscopic, surgical/ histopathological, radiological and clinical findings, according to the Lennard-Jones criteria ${ }^{(14)}$. All patients underwent colonoscopy and biopsies. Disease location was considered the maximum extent of involvement at present (in patients who did not undergo surgical resection) or at any time before the first surgical resection.

Demographic information on sex, age and race were evaluated (including Jewish ascendance), as well as data concerning clinical onset of disease, date of diagnosis, age at diagnosis, time of disease (in years), location and behavior of disease, presence of extraintestinal manifestations, familial occurrence, perianal involvement, treatment with biological drugs, and history of surgical treatment.

Race was characterized based on skin color, according to patient's self-assessment, who could choose between the following options, as classified by Brazilian Census of The Brazilian Institute of Geography and Statistics (IBGE): white, black, brown, yellow, and indigenous ${ }^{(11)}$. With respect to history of surgical treatment, abdominal and anal surgery were taken into account distinctly, for avoiding the bias of comparing total surgical procedures, some due to perianal disease (a disease modifier on $\mathrm{MC}$, as already mentioned) with categories and variables of $\mathrm{MC}$ in statistical analysis. All patients were characterized according to $\mathrm{MC}$.

\section{Ethical aspects}

The present study is part of a larger research project that has been conducted at our institution, investigating the clinical epidemiology of IBD in Northwestern of São Paulo State; data utilized in this study pertain to the same database specially created to the main project. The Ethics Committee Medical School of São José do Rio Preto approved the study (protocol \# 1763/2008, approval 081/2008).

\section{Statistical analysis}

Descriptive statistics were performed to obtain frequency distribution and variability of studied variables, as appropriate. Kruskal-Wallis nonparametric test was used to test hypotheses about continuous variables. Chi-square test and Fisher's exact 
test were used to test hypotheses about categorical variables. Linear association between variables was identified by linear regression. A $P<0.05$ was considered a priori to be statistically significant. All statistical analyses were performed using the statistical software package Systat 12 for Windows (Systat Software $^{\circledR}$, Inc. 2007).

\section{RESULTS}

Of the $90 \mathrm{CD}$ patients, 49 were male (54\%), with a mean age at diagnosis of 33 years old and a median follow-up of 5.5 years (range, 2-17 years); 74 patients were self-identified as white $(82 \%), 9$ as brown $(10 \%)$, and 7 as black $(8 \%)$. No patient reported Jewish ascendance. Extraintestinal manifestations were identified in $16 \%$ of patients and only $2 \%$ related familial occurrence of CD. Seventeen patients were either smokers or ex-smokers (19\%). Data concerning baseline characteristics of all patients are shown in Table 1.

TABLE 1. Baseline characteristics of all CD patients according to age at diagnosis

\begin{tabular}{|c|c|c|c|c|}
\hline & \multicolumn{3}{|c|}{ Age at diagnosis } & \multirow{2}{*}{$\begin{array}{c}\text { All } \\
\text { n (\%) }\end{array}$} \\
\hline & $\begin{array}{c}\mathrm{A} 1 \text { ( } \leq 16 \text { years }) \\
\mathrm{n}(\%)\end{array}$ & $\begin{array}{c}\text { A2 (17 to } 40 \text { years) } \\
\text { n }(\%)\end{array}$ & $\begin{array}{c}\text { A3 ( }>40 \text { years) } \\
\text { n }(\%)\end{array}$ & \\
\hline \multicolumn{5}{|l|}{ Sex } \\
\hline Male & $4(57)$ & $29(55)$ & $16(53)$ & $49(54)$ \\
\hline Female & $3(43)$ & $24(45)$ & $14(47)$ & $41(46)$ \\
\hline Age $($ mean \pm SD) & $13 \pm 4$ & $28 \pm 7$ & $50 \pm 10$ & $\begin{array}{c}33 \pm \\
14\end{array}$ \\
\hline \multicolumn{5}{|l|}{ Race } \\
\hline White & $6(86)$ & $48(91)$ & $20(67)$ & $74(82)$ \\
\hline Brown & - & $5(9)$ & $4(13)$ & $9(10)$ \\
\hline Black & $1(14)$ & - & $6(20)$ & $7(8)$ \\
\hline Others & - & - & - & - \\
\hline Years of disease (median) & 6 & 6 & 4,5 & 5,5 \\
\hline $\begin{array}{l}\text { Extraintestinal } \\
\text { manifestations }\end{array}$ & - & 7 & 7 & $14(16)$ \\
\hline Familial occurrence & - & 2 & - & $2(2)$ \\
\hline Smoking & - & 6 & 11 & $17(19)$ \\
\hline
\end{tabular}

In relation to the use of biological drugs, 18 patients (21\%) were treated in some time of disease with this therapeutic modality; necessity of surgical interventions (excluding those related to perianal disease) was identified in 28 patients (31\%).

Considering age at diagnosis, most of the patients were classified as A2 (59\%), 33\% as A3, and $8 \%$ as A1. Disease located in the terminal ileum (L1) was found in 41 patients $(46 \%), 4$ of whom with concomitant upper gastrointestinal involvement ( $\left.\mathrm{L1}_{4}\right)$. Colonic onset (L2) was observed in $10 \%$, and $44 \%$ had ileocolonic disease (L3); only 1 patient had upper gastrointestinal onset associated to ileocolonic disease $\left(\mathrm{L}_{4}\right)$. None of patients had exclusive upper gastrointestinal onset (L4). In respect to disease behavior, 64 patients (71\%) were allocated in B1 group (nonstricturing, nonpenetrating); in this group, 21 patients $(33 \%)$ had perianal disease (B1p). Stricturing disease (B2) was found in 7 patients $(8 \%)$, of whom 2 had perianal disease (B2p). Penetrating behavior of disease (B3) was present in 19 patients (21\%), of whom 5 had concomitant perianal disease (B3p). Table 2 shows allocation of patients according to age at diagnosis, location and behavior of the disease. Given the significant proportion of patients with perianal disease, the characteristics of this group were separately analyzed (Table 3 ); results showed a slight male predominance and a higher mean age; the median time of disease was similar to that noted among all the patients.

TABLE 2. Characterization of a cohort of $90 \mathrm{CD}$ patients according to the Montreal Classification

\begin{tabular}{|c|c|c|c|c|}
\hline & $\begin{array}{l}\text { A1 ( } \\
\mathrm{n}\end{array}$ & $\begin{array}{c}\text { A2 (17 to } 40 \text { years }) \\
n\end{array}$ & $\begin{array}{l}\text { A3 ( }>40 \text { years }) \\
\mathrm{n}\end{array}$ & $\begin{array}{c}\text { All } \\
\mathrm{n}(\%)\end{array}$ \\
\hline \multicolumn{5}{|l|}{ Location * } \\
\hline L1 (TI) & 2 & 22 & 13 & $37(41.1)$ \\
\hline $\mathrm{L}_{4}(\mathrm{TI}+\mathrm{UGI})$ & - & 3 & 1 & $4(4.5)$ \\
\hline $\mathrm{L}_{2}(\mathrm{C})$ & 1 & 4 & 4 & $9(10)$ \\
\hline $\mathrm{L} 2_{4}(\mathrm{C}+\mathrm{UGI})$ & - & - & - & - \\
\hline L3 (IC) & 4 & 23 & 12 & $39(43.3)$ \\
\hline $\mathrm{L}_{4}(\mathrm{IC}+\mathrm{UGI})$ & - & 1 & - & $1(1.1)$ \\
\hline L4 (UGI) & - & - & - & - \\
\hline \multicolumn{5}{|l|}{ Behavior $\dagger$} \\
\hline B1 (NSNP) & 5 & 22 & 16 & $43(47.8)$ \\
\hline $\mathrm{B} 1 \mathrm{p}(\mathrm{NSNP}+\mathrm{p})$ & 1 & 15 & 5 & $21(23.3)$ \\
\hline B2 (S) & - & 2 & 3 & $5(5.6)$ \\
\hline $\mathrm{B} 2 \mathrm{p}(\mathrm{S}+\mathrm{p})$ & - & 1 & 1 & $2(2.2)$ \\
\hline B3 (P) & 1 & 9 & 4 & $14(15.5)$ \\
\hline $\mathrm{B} 3 \mathrm{p}(\mathrm{P}+\mathrm{p})$ & - & 4 & 1 & $5(5.6)$ \\
\hline \multicolumn{5}{|c|}{$\begin{array}{l}\text { *TI = terminal ileum, with or without cecum involvement; UGI = upper gastrointestinal tract; } \\
\mathrm{C}=\text { colon; IC = ileocolonic } \\
\dagger \mathrm{NSNP}=\text { nonstricturing, nonpenetrating; } \mathrm{S}=\text { stricturing; } \mathrm{P}=\text { penetrating; } \mathrm{P}=\text { perianal fistulizing disease }\end{array}$} \\
\hline \multicolumn{5}{|c|}{ TABLE 3. Baseline characteristics of CD patients with perianal disease } \\
\hline & & \multicolumn{3}{|c|}{ All $=28 \mathrm{n}(\%)$} \\
\hline \multicolumn{5}{|l|}{ Sex } \\
\hline Male & & & $16(57)$ & \\
\hline Female & & & $12(43)$ & \\
\hline Age $($ mean $\pm S D)$ & & & $41 \pm 14$ & \\
\hline \multicolumn{5}{|l|}{ Race } \\
\hline White & & & $25(89)$ & \\
\hline Brown & & & $2(7)$ & \\
\hline Black & & & $1(4)$ & \\
\hline Others & & & - & \\
\hline \multicolumn{2}{|c|}{ Age at diagnosis $($ mean $\pm \mathrm{SD})$} & & $34 \pm 14$ & \\
\hline \multicolumn{2}{|c|}{ Years of disease (median) } & & 6.1 & \\
\hline \multicolumn{2}{|c|}{ Extraintestinal manifestations } & & $1(4)$ & \\
\hline \multicolumn{2}{|l|}{ Familial occurrence } & & - & \\
\hline \multicolumn{2}{|l|}{ Smoking } & & $6(21)$ & \\
\hline
\end{tabular}

Significant gender differences were found regarding disease location; female patients tended to have more ileocolonic involvement than male patients, and exclusive involvement of the terminal ileum was higher in male patients $(P=0.036)$. Figure 1 exhibits disease location according to patient gender. No significant differences were identified between genders in relation to disease behavior; moreover, differences between age at diagnosis, location and behavior of the disease were not observed to be statistically significant. Presence of perianal disease was not statistically associated with sex, age at diagnosis, time of disease or use of biological drugs. 


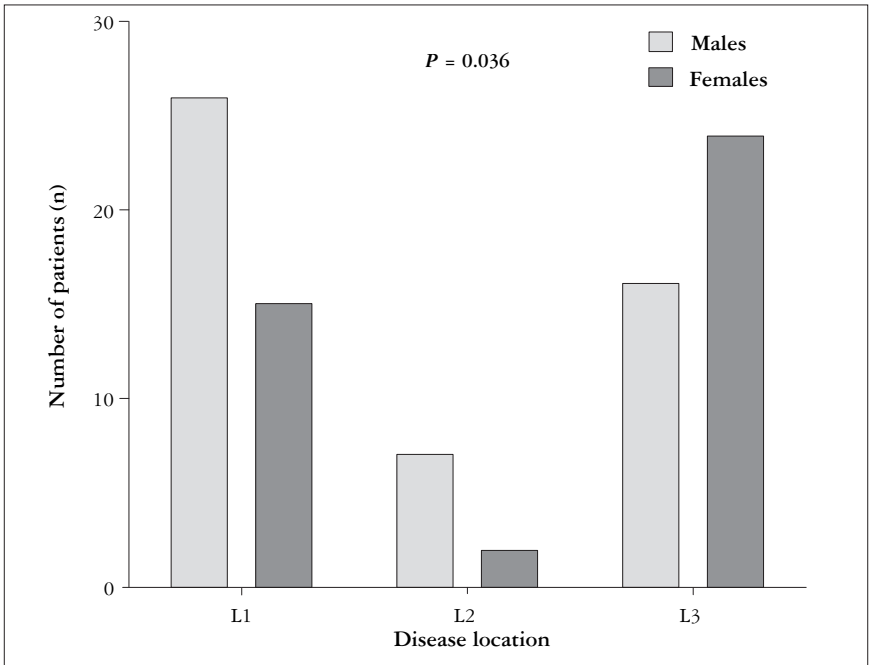

FIGURE 1. Disease location according to gender, in number of patients. Cases with concomitant upper gastrointestinal involvement (L4) are also included

Necessity of biological treatment trended to be correlated with higher median time of disease (median of 8.5 years vs 5.5 years; $P=0.028$ ) and higher occurrence of surgical treatment (78\% vs $44 \% ; P=0.011)$. In addition, surgical treatment was also related to higher rates of $\mathrm{B} 1$ and $\mathrm{B} 3$ than $\mathrm{B} 2$ behavior $(P<0.0001)$ and higher median time of disease (median of 7.5 years vs 4.7 years; $P<0.0001$ ). No substantial differences were found between occurrence of surgical intervention and disease location.

Comparing time of disease to location and behavior of the disease, patients with $\mathrm{B} 1$ behavior presented a lesser median time of disease than those with B2 and B3 behavior (5.2 years vs 10.6 years and 7.4 years, respectively; $P=0.018)$. Figure 2 exhibits the percentage of patients allocated in three groups according to time of disease (below 5 years, 5 to 10 years, and above 10 years) and disease behavior. The percentage of B1 patients declined proportionally to the increase in years of disease $(P=0.041)$; in a distinct manner, the percentage of B2 and B3 patients trended to be higher according to the rise in years of disease $(P=0.041)$. Comparison between disease location and median time of disease was not statistically significant.

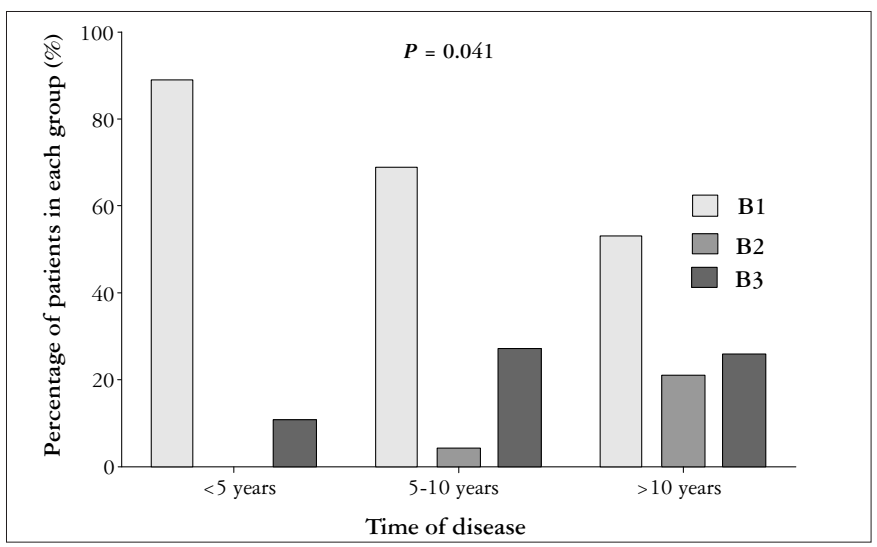

FIGURE 2. Percentage of patients allocated in three groups pursuant to time of disease and disease behavior

\section{DISCUSSION}

In the recent years, innumerable advances have occurred in the field of IBD pathogenesis: more genetic factors have being established with basis on genome-wide association studies, the role of mucosal immune regulatory system is becoming better understood, and new evidence about the importance of environmental factors has been found. Moreover, new targets and therapeutic approaches are being used, as monoclonal antibodies, for example ${ }^{(2,25)}$. In this same sense, an increasing necessity of classifying CD patients in the light of multiple recent clinical, molecular, and genetic advances has been observed. The MC represents, thus, an important attempt to relate clinical practice to research progress ${ }^{(26)}$.

Considering baseline characteristics of CD patients enrolled in the present study, there were not significant differences about female to male ratio, or mean age of each group according to age at diagnosis, in comparison to larger studies $^{(3,7,17)}$. In addition, no significant differences were identified comparing race to other variables; in this sense, a large multicentric study comparing white with black CD patients did not find differences with respect to age of onset, disease presentation and course, and rates of hospitalization and surgeries ${ }^{(28)}$; this enables to question how important is to consider the variable race in CD.

The variable age at diagnosis, that is proper to assess time-dependent consequences of CD, in several studies has been related to disease location, gender, and familial history $(10,18,21)$. In 1996 , Polito et al. ${ }^{(21)}$, analyzing a cohort of 552 consecutive patients, found that a lesser age at diagnosis was associated with higher rates of familial history of CD, small bowel onset, stricturing disease, and surgery; younger age at diagnosis was also correlated with genetic factors ${ }^{(12)}$. Therefore, by adding a more refined pediatric category to this variable, MC allowed that future studies could confirm the age effects on diagnosis about the behavior of CD.

Applying MC to a cohort of 1,015 patients, Freeman ${ }^{(7)}$ found that penetrating disease complications were correlated to a younger age at diagnosis. In this studied population, the majority of patients had between 17 and 40 years of age, according to the classical epidemiological pattern of $\mathrm{CD}^{(19)}$. Nevertheless, the patients in A1 group predominantly had ileocolonic involvement and nonstricturing, nonpenetrating behavior, despite presenting similar median time of disease in comparison with the other age groups. Therefore, no specific characteristics of worse disease evolution were observed in this group, although the limited number of patients in this age group might be responsible for these results.

In respect to the disease location, the studied population revealed a higher frequency of ileocolonic (44\%) and exclusive ileal involvement (46\%); only a small percentage had exclusive colonic onset. These findings are partly similar to a large Portuguese multicentric study recently published. Researchers applied MC for CD to 1692 patients; results showed that most of patients had ileocolonic manifestations (45\%), followed by exclusive ileal onset (34\%), and exclusive colonic involvement $(15 \%)$; only $1 \%$ had upper gastrointestinal onset ${ }^{(17)}$. Considering 
disease behavior, the findings of the present study show that the majority of patients had nonstricturing, nonpenetrating behavior; this differs from some studies using VC, which show a predominant B3 behavior ${ }^{(4,6,15)}$. Such predominance can be explained by the fact of considering perianal disease in group of penetrating behavior. Studies applying MC show predominant B1 behavior ${ }^{(3,17)}$. The relatively short mean follow-up of 5.5 years in the present study, likewise, might have contributed to these findings, inasmuch as the disease behavior seems to change over time ${ }^{(15,16)}$, as will be further discussed below.

In the present study, statistically significant differences between age at diagnosis, location and disease behavior were not found. This can be explained by the limited size of the sample. However, disease duration revealed to be correlated with necessity of biological treatment, disease behavior, and surgical treatment. Similar findings were revealed by a study analyzing a pediatric cohort of CD patients, in which disease duration was considered a predictor for disease behavior ${ }^{(24)}$; moreover, another single-cohort study revealed that disease behavior changes over time, according to disease duration, and an early development of stricturing or penetrating behavior is also influenced by disease location ${ }^{(16)}$.

Indeed, the observation that disease behavior changes over time was made in 2001, by Louis et al. ${ }^{(15)}$. The authors found that over 10 years, $45.9 \%$ of patients had a change in disease behavior; the most significant changes were from $\mathrm{B} 1$ to $\mathrm{B} 2$ or $\mathrm{B} 3$ behavior ${ }^{(15)}$. Another recent study considering 340 well-characterized $\mathrm{CD}$ patients showed that perianal disease, disease location, and smoking are some independent predictors of disease behavior change ${ }^{(13)}$. In the present study the changing of disease behavior over time was not assessed; on the other hand, patients were grouped according to disease duration; the results showed that patients with higher disease duration ( $>10$ years) had lesser rates of $\mathrm{B} 1$ behavior and higher rates of $\mathrm{B} 2$ and $\mathrm{B} 3$ behavior, when compared to those with lesser disease duration ( $<10$ years). This can suggest that patients with B1 behavior at diagnosis present an evolution to stricturing or penetrating disease over time, although a prospective study would be required to fully confirm this hypothesis.

In conclusion, it is important to emphasize that, even though in various recent studies MC has been able to exhibit prognostic and clinically relevant differences among the specific subgroups of CD patients, some aspects of this classification need a more accurate analysis, based on international and independent studies among different populations. Allying clinical and research progresses toward an integrated classification is challenging, but it depends on combined efforts, for defining not only a more profound knowledge about CD pathophysiology, but also better and directed therapies, with advantages to the patient.

Torres US, Rodrigues JO, Junqueira MSG, Uezato S, Netinho JG. Classificação de Montreal para doença de Crohn: aplicação clínica em uma coorte brasileira de 90 pacientes consecutivos. Arq Gastroenterol. 2010;47(3):279-84.

RESUMO - Contexto - A doença de Crohn apresenta características bastante heterogêneas clinicamente, de modo que a classificação dos pacientes com a doença em subgrupos homogêneos de acordo com aspectos clínicos, moleculares e genéticos é tarefa desafiadora. A Classificação de Montreal para a doença de Crohn foi proposta em 2005 como um esforço no sentido de caracterizar pacientes com doença de Crohn de acordo com os recentes avanços clínicos e de pesquisa no campo das doenças inflamatórias intestinais. Desde sua proposição, a Classificação de Montreal necessita de uma ampla validação e aplicação entre diferentes populações ao redor do mundo. Não há até aqui, segundo se sabe, estudos aplicando a Classificação de Montreal em uma coorte brasileira de pacientes com doença de Crohn. Objetivos - Aplicar a Classificação de Montreal a uma coorte brasileira de pacientes com doença de Crohn atendidos em um centro de referência para doenças inflamatórias intestinais no noroeste do Estado de São Paulo, Brasil. Métodos - Foram selecionados 90 pacientes com diagnóstico bem caracterizado de doença de Crohn, atendidos consecutivamente em ambulatório de doenças inflamatórias intestinais entre janeiro de 1992 e janeiro de 2007, com seguimento mínimo de 2 anos; foram avaliados dados referentes às características demográficas, manifestações clínicas da doença, idade ao diagnóstico, tempo de doença, localização e comportamento da doença, presença de manifestações extraintestinais, história familiar de doença de Crohn, manifestações perianais, tratamento com drogas biológicas e história de tratamento cirúrgico. Resultados - Houve predomínio de pacientes do sexo masculino (54\%), com média de idade ao diagnóstico de $33 \pm$ 14 anos e seguimento com mediana de 5,5 anos. A maior parte dos pacientes foi diagnosticada com idade entre 17 e 40 anos (59\%), e possuía doença localizada no íleo terminal (46\%), com comportamento não-estenosante e não-penetrante $(71 \%)$. O tempo de doença associou-se à necessidade de tratamento com drogas biológicas, comportamento da doença e tratamento cirúrgico $(P<0,05)$. Conclusões - Os achados do presente estudo são compatíveis com resultados de outros estudos realizados com diferentes populações, embora outro estudo multicêntrico, com maior número de pacientes, possa ser necessário para validar a Classificação de Montreal entre a população brasileira.

DESCRITORES - Doença de Crohn, classificação. 


\section{REFERENCES}

1. Achkar JP, Brzezinski A. Interobserver agreement for disease behaviour phenotype in Crohn's disease [abstract]. Gastroenterology. 2002;122(Suppl):W1293.

2. Asakura H, Suzuki K, Honma T. Recent advances in basic and clinical aspects of inflammatory bowel disease: which steps in the mucosal inflammation should we block for the treatment of inflammatory bowel disease? World J Gastroenterol 2007;13:2145-9.

3. Chow DK, Leong RW, Lai LH, Wong GL, Leung WK, Chan FK, Sung JJ. Changes in Crohn's disease phenotype over time in the Chinese population: validation of the Montreal classification system. Inflamm Bowel Dis. 2008;14:536-41.

4. Dorn SD, Abad JF, Panagopoulos G, Korelitz BI. Clinical characteristics of familial versus sporadic Crohn's disease using the Vienna Classification. Inflamm Bowel Dis. 2004;10:201-6.

5. Farmer RG, Hawk WA, Turnbull RB Jr. Clinical patterns in Crohn's disease: a statistical study of 615 cases. Gastroenterology. 1975;68:627-35.

6. Freeman HJ. Application of the Vienna Classification for Crohn's disease to a single clinician database of 877 patients. Can J Gastroenterol. 2001;15:89-93.

7. Freeman HJ. Application of the Montreal classification for Crohn's disease to a single clinician database of 1015 patients. Can J Gastroenterol. 2007;21:363-6.

8. Gasche C, Scholmerich J, Brynskov J, D’Haens G, Hanauer SB, Irvine EJ, Jewell DP, Rachmilewitz D, Sachar DB, Sandborn WJ, Sutherland LR. A simple classification of Crohn's disease: report of the Working Party for the World Congresses of Gastroenterology, Vienna 1998. Inflamm Bowel Dis. 2000;6:8-15.

9. Greenstein AJ, Lachman P, Sachar DB, Springhom J, Heimann T, Janowitz HD, Aufses AH Jr. Perforating and non-perforating indications for repeated operations in Crohn's disease: evidence for two clinical forms. Gut. 1988;29:588-92.

10. Heyman MB, Kirschner BS, Gold BD, Ferry G, Baldassano R, Cohen SA, Winter HS, Fain P, King C, Smith T, El-Serag HB. Children with early-onset inflammatory bowel disease (IBD): analysis of a pediatric IBD consortium registry. J Pediatr. 2005; $146: 35-40$.

11. IBGE (Fundação Instituto Brasileiro de Geografia e Estatística). Contagem da população. Rio de Janeiro; 2000.

12. Ideström M, Rubio C, Granath F, Finkel Y, Hugot JP. CARD15 mutations are rare in Swedish pediatric Crohn disease. J Pediatr Gastroenterol Nutr. 2005;40:456-60.

13. Lakatos PL, Czegledi Z, Szamosi T, Banai J, David G, Zsigmond F, Pandur T, Erdelyi Z, Gemela O, Papp J, Lakatos L. Perianal disease, small bowel disease, smoking, prior steroid or early azathioprine/biological therapy are predictors of disease behavior change in patients with Crohn's disease. World J Gastroenterol. 2009; 15:3504-10

14. Lennard-Jones JE. Classification of inflammatory bowel disease. Scand J Gastroenterol Suppl. 1989;170:2-6.

15. Louis E, Collard A, Oger AF, Degroote E, Aboul Nasr El Yafi FA, Belaiche J. Behaviour of Crohn's disease according to the Vienna classification: changing pattern over the course of the disease. Gut. 2001;49:777-82
16. Louis E, Michel V, Hugot JP, Reenaers C, Fontaine F, Delforge M, El Yafi F, Colombel JF, Belaiche J. Early development of stricturing or penetrating pattern in Crohn's disease is influenced by disease location, number of flares, and smoking but not by NOD2/CARD15 genotype. Gut. 2003;52:552-7.

17. Magro F, Portela F, Lago P, Ramos de Deus J, Vieira A, Peixe P, Cremers I, Cotter J, Cravo M, Tavares L, Reis J, Gonçalves R, Lopes H, Caldeira P, Ministro P, Carvalho L, Azevedo L, da Costa-Pereira A; GEDII. Crohn's disease in a southern European country: Montreal classification and clinical activity. Inflamm Bowel Dis. 2009;15:1343-50.

18. Meinzer U, Ideström M, Alberti C, Peuchmaur M, Belarbi N, Bellaïche M, Mougenot JF, Cézard JP, Finkel Y, Hugot JP. Ileal involvement is age dependent in pediatric Crohn's disease. Inflamm Bowel Dis. 2005; 11:639-44.

19. Munkholm P. Crohn's disease: occurrence, course and prognosis: an epidemiologic cohort-study. Dan Med Bull. 1997;44:287-302.

20. Podolsky DK. Inflammatory bowel disease. N Engl J Med. 2002;347:417-29.

21. Polito JM, Childs B, Mellits ED, Tokayer AZ, Harris ML, Bayless TM. Crohn's disease: influence of age at diagnosis on site and clinical type of disease. Gastroenterology. 1996;111:580-6.

22. Sachar DB, Andrews HA, Farmer RG, Pallone F, Pena AS, Prantera C, Rutgeerts P. Proposed classification of patient subgroups in Crohn's disease. Gastroenterol Int. 1992;5:141-54.

23. Satsangi J, Silverberg MS, Vermeire S, Colombel JF. The Montreal classification of inflammatory bowel disease: controversies, consensus, and implications. Gut. 2006;55:749-53.

24. Shaoul R, Karban A, Reif S, Weiss B, Shamir R, Tamir A, Davidovich O, Halevi J, Silver EL, Levine A. Disease behavior in children with Crohn's disease: the effect of disease duration, ethnicity, genotype, and phenotype. Dig Dis Sci. 2009;54:142 50 .

25. Shih DQ, Targan SR, McGovern D. Recent advances in IBD pathogenesis: genetics and immunobiology. Curr Gastroenterol Rep. 2008;10:568-75.

26. Silverberg MS, Satsangi J, Ahmad T, Arnott ID, Bernstein CN, Brant SR, Caprilli R, Colombel JF, Gasche C, Geboes K, Jewell DP, Karban A, Loftus Jr EV, Peña AS, Riddell RH, Sachar DB, Schreiber S, Steinhart AH, Targan SR, Vermeire S, Warren BF. Toward an integrated clinical, molecular and serological classification of inflammatory bowel disease: report of a Working Party of the 2005 Montrea World Congress of Gastroenterology. Can J Gastroenterol. 2005;19:5-36.

27. Smith BR, Arnott ID, Drummond HE, Nimmo ER, Satsangi J. Disease location, anti-Saccharomyces cerevisiae antibody, and NOD2/CARD15 genotype influence the progression of disease behavior in Crohn's disease. Inflamm Bowel Dis. 2004;10:521-8.

28. Straus WL, Eisen GM, Sandler RS, Murray SC, Sessions JT. Crohn's disease: does race matter? - The mid-Atlantic Crohn's Disease Study Group. Am J Gastroenterol. 2000;95:479-83. 